дедалі частіше показувала свою неспроможність у процесі охорони законності та правопорядку не могла забезпечити необхідну правову захищеність життєво важливих інтересів суб'єктів права. Тому конституційна реформа, повинна забезпечить докорінну трансформацію національної правової системи, стати соціальним середовищем функціонування конституційноправової науки як спеціалізованої діяльності, яка має теоретичноприкладний характер, та підгрунтям для формування змісту наукових конституційноправових досліджень.

\title{
Література:
}

1. Калініченко О.Ф. Конституційний процес та напрямки новітньої конституційної реформи в Україні // De Lege Ferenda. Юридичний науковий електронний журнал / Харків., «Стиль-Іздат». Осінь. 2016. С. 8-10.

2. Оніщенко Н. Відродження поваги до права в контексті розвитку правової свідомості та правової усвідомленості / Н. Оніщенко [Onishchenko N. Renewal of respect for the law in the context of legal consciousness' and legal awareness' development] // Biчe. - 2014. № 9. - C. 44-45.

3. Малишев Б. В. Правова система (телеологічний вимір): Монографія / Б. В. Малишев [Malyshev B. Legal system (teleological dimension): Monograph]. - К.: «ВД «Дакор», 2012. - 364 c.

4. Пєтков С. В. Народовладдя: від права радянського до права громадянського / С. В. Пєтков [Pietkov S. Popular rule: From the Soviet to civic law]. - К.: Видавничий дім «Скіф», 2014. - 56 c.

DOI https://doi.org/10.30525/978-9934-26-148-0-17

\section{ПЕРСПЕКТИВИ ЗАСТОСУВАННЯ ШТУЧНОГО ІНТЕЛЕКТУ У ВИБОРЧОМУ ПРОЦЕСІ УКРАЇНИ}

\section{Кармаза О. О.}

доктор юридичних наук, професор

Інституту післядипломної освіти

Київського начіонального університету

імені Тараса Шевченка

м. Київ, Украӥна

На сьогодні використання Інтернету в Україні та в світі може розглядатися як реалізація основоположних прав та свобод людини i 
громадян, та становлять основу демократичного суспільства. Крім того, в різних сферах суспільного життя, включно і у виборчому процесі, цифрові технології займають особливе місце. Так, наприклад, мова йде про оцифровані списки виборців, реєстр кандидатів, які існують в електронному форматі тощо. Разом 3 тим практичне застосування цифрових технологій загалом та штучного інтелекту зокрема це складне завдання.

Складність полягає: у наявності належної нормативно-правової бази щодо їх застосування; здійснені заходів щодо кібербезпеки; не порушенні основних принципів виборчого процесу, дотриманні основоположних прав та свобод людини і громадянина, закріплених на міжнародному та національному рівнях; належному технічному забезпеченні забезпечені відповідних е-програм; наявності знань та вмінь у їх застосуванні громадянами; довірі суспільства тощо.

До новітніх технологій, які впровадженні у світі чи плануються запровадити у виборчий процес України, зокрема відносяться діджиталізація документів і процедур, біомертія, блокчейн, штучний інтелект (далі - ШІ) тощо. Так, наприклад, Президент України В. Зеленський у межах робочого візиту до США відвідав Стенфордський університет (Каліфорнія) та виступив перед експертним середовищем цього навчального закладу. Зокрема, він зазначив, що «ми прагнемо, щоб усі громадяни України мали можливість голосувати на виборах в Інтернеті» [1]. Крім того, ст. 101 Закону України «Про всеукраїнський референдум» передбачено електронне голосування виборців на всеукраїнському референдумі.

Застосування ШІ в сучасних умовах розвитку суспільних відносин, його вплив на права людини $є$ предметом дослідження науковців, міжнародних організацій тощо. Так, Рада Свропи проводить оцінку та прогнозування впливу цифрових технологій на права людини, демократію та верховенство права, розробляє правові інструменти щоб люди скористалися перевагами інноваційної практики [2]. Україна, будучи членом Спеціального комітету зі штучного інтелекту при Раді Європи, приєдналася до Рекомендацій Організації економічного співробітництва і розвитку з питань штучного інтелекту [3], а в грудні 2020 року розпорядженням Кабінету Міністрів України схвалила Концепцію розвитку штучного інтелекту в Україні [4].

Натомість зміст поняття «штучний інтелект» в Україні офіційно не розкрито, не визначено види ШІ, принципи використання, межі, умови, порядок застосування тощо. Метою створення ШІ $\epsilon$ копіювання (моделювання) роботи людського мозку (інтелекту, розумової діяльності тощо) за рахунок відтворення когнітивної функції 
еквівалентних (тотожних) за критеріями, характеристиками і показниками конгнітивним функціям людини. ШІ - це сукупність методів, способів, технологій і засобів, в тому числі, апаратних, та комп'ютерних програм, які реалізують одну, кілька або всі когнітивні функції еквівалентні когнітивним функціям людини [5]. Сдиної відповіді на питання, чим опікується штучний інтелект не існує [6], тож запровадження ШІ $\epsilon$ специфічним для кожної окремої сфери відносин.

В Рекомендаціях CM/Rec (2020)1 про вплив алгоритмічних систем на права людини Комітету міністрів Ради Свропи 8 квітня 2020 р. наголошується, що при розробці та запровадженні алгоритмічних систем слід дотримуватися норм та принципів, викладених в Європейській конвенції з прав людини, які є універсальними, неподільними, взаємозалежними та взаємопов'язаними, щоб посилити позитивний ефект та запобігти або мінімізувати можливі несприятливі наслідки. Тобто, дотримуватися принципу верховенства права, принципу законності, принципу прозорості, принципу передбачуваності, принципів вільних та чесних демократичних виборів тощо при запровадженні різних форм (видів) ШІ.

На нашу думку, ШІ у майбутньому може застосовуватися у виборчому процесі, зокрема, для недопущення кібератак (кіберзахист), в просвіті суб'єктів виборчого процесу, контролю за дотриманням строків у виборчому процесі тощо. Разом з тим, використання ШІ у виборчому процесі повинно відбуватися із дотриманням прав людини (людина у центрі уваги), із забезпеченням принципів вільних та демократичних виборів, на підставі довіри суспільства, а рішення ШІ піддаватися поясненню (людина несе відповідальність, а не е-особистість) тощо. ШІ може змінити філософію та правову природу деяких етапів виборчого процесу, дозволить адаптувати юридичні процеси під розвиток суспільних відносин, які існують на час його запровадження, але 3 дотриманням моральних та процесуальних норм щодо застосування різних проявів ШІ.

\section{Література:}

1. Офіційне інтернет-представництво Президент України. Володимир Зеленський. Електронний документ. Режим доступу: https://www.president.gov.ua/news/volodimir-zelenskij-vistupiv-ustenfordskomu-universiteti-uk-70521

2. Рада Європи та штучний інтелект. Електронний документ. Режим доступу: https:/www.coe.int/en/web/artificial-intelligence/home 
3. Organisation for Economic Co-operation and Development, Recommendation of the Council on Artificial Intelligenc. Режим доступу: https://legalinstruments.oecd.org/en/instruments/OECD-LEGAL-0449

4. Урядовий портал. Сдиний веб-портал органів виконавчої влади. Електронний документ. Режим доступу: https://www.kmu.gov.ua/npas/ pro-shvalennya-koncepciyi-rozvitku-shtuchnogo-intelektu-v-ukrayinis21220

5. Баранов О.А. Ідентифікація робота 3 штучним інтелектом як суб'єкта права. Інтернет речей: проблеми правового регулювання та впровадження. Матеріали другої наук.-практ. конф. Упор. В.М. Фурашев, С.О. Дорогих. К. 2018. 168 с.

6. Вікіпедія. Штучний інтелект. Електронний документ. Режим доступу: https://uk.wikipedia.org/wiki/\%D0\%A8\%D1\%82\%D1\%83\%D1\% 87\%D0\%BD\%D0\%B8\%D0\%B9_\%D1\%96\%D0\%BD\%D1\%82\%D0\%B5\% D0\%BB\%D0\%B5\%D0\%BA\%D1\%82

DOI https://doi.org/10.30525/978-9934-26-148-0-18

\title{
СУЩНОСТЬ ИННОВАЦИОННОЙ ДОКТРИНЫ АНТИДЕЛИКТНЫХ ОРГАНОВ И АНТИДЕЛИКТОЛОГОВ
}

\author{
Кириченко А. А.
}

доктор юридических наук, профессор, заведующий кафедрой права факультета экономики и права

Международного классического университета имени Филиппа Орлика

Садовская К. С.

соискатель высшего образования по спечиальности 081 Право квалификационного уровня младший бакалавр факультета экономики и права Международного классического университета имени Филиппа Орлика 2. Николаев, Украина

Инновационные наименования и перечень антиделиктных органов и антиделиктологов следует представить так : 1. Суд, судья. 2. Прокуратура, прокурор. 3. Публичнотура, преследователь. 4. Адвокатура, адвокат. 5. Следотура, следователь. 6. Экспертнотура, эксперт. 7. Госбезопаснотура, сотрудник госбезопасности. 8. Ордистатура, 